\title{
Virus Accumulation and Whitefly Performance Modulate the Role of Alternate Host Species as Inoculum Sources of Tomato Yellow Leaf Curl Virus
}

\author{
Saioa Legarrea, Apurba Barman, Stanley Diffie, and Rajagopalbabu Srinivasan ${ }^{\dagger}$ \\ Department of Entomology, University of Georgia, Tifton, GA 31793
}

\begin{abstract}
Evaluating alternate hosts that facilitate the persistence of a virus in the landscape is key to understanding virus epidemics. In this study, we explored the role of several plant species (eggplant, pepper, and Palmer amaranth) as inoculum sources of tomato yellow leaf curl virus (TYLCV) and as reservoirs for its insect vector, Bemisia tabaci (Gennadius). All inoculated species were infected with TYLCV, but whiteflies acquired fewer viral copies via feeding from pepper and eggplant than from tomato and Palmer amaranth. Further, back-transmission assays to recipient tomato resulted in TYLCV infection only when TYLCV was acquired from

of viral copies in the plant, and consequently in the insect vector. In addition, results showed that all three alternate species could sustain populations of $B$. tabaci, while differentially influencing fitness of whiteflies. Eggplant was a superior host for whiteflies, whereas whitefly survival was compromised on pepper. Together, we demonstrate that both plantvirus and plant-vector interactions could influence the role of an alternate host in TYLCV epidemics, and in our region of study we highlight the potential risk of hosts such as Palmer amaranth in the spread of TYLCV.
\end{abstract} Palmer amaranth or tomato. Analysis suggested that the role of plant species as TYLCV inoculum sources may be determined by the accumulation
Keywords: Begomovirus, alternate host, Bemisia tabaci, virus transmission
Alternate plant hosts that act as virus inoculum sources could play an important role in the persistence and spread of the virus in the landscape (Duffus 1971). Therefore, the identification and evaluation of such inoculum sources are key elements to understanding the epidemiology and ecology of a phytovirus in an agroecosystem. Such an evaluation should be conducted at both the organismal and the landscape level (Alexander et al. 2014), because infections by viral pathogens in multiple hosts may be unnoticeable due to asymptomatic infections (Malmstrom et al. 2011; Prendeville et al. 2012; Raybould et al. 1999).

Tomato yellow leaf curl virus is a species in the genus Begomovirus in the family Geminiviridae. Tomato yellow leaf curl virus (TYLCV) is a major pathogen of tomato (Solanum lycopersicum L.) worldwide and can cause complete yield loss, especially when infections occur at an early stage (Moriones and Navas-Castillo 2000; Scholthof et al. 2011). This virus was first reported in the American continent in the 1990s (Polston et al. 1999), and since then annual outbreaks occur in the southeastern United States (Adkins et al. 2011; Polston et al. 1999; Riley and Srinivasan 2019; Smith et al. 2018; Srinivasan et al. 2012). Even though the tomato crop itself is considered the major reservoir of TYLCV (Adkins et al. 2011), tomato is not grown year-round in this region, and alternate hosts could be relevant in recurring annual TYLCV epidemics. Identifying alternate hosts that are susceptible to TYLCV has been a major aim since the emergence of TYLCV epidemics (Cohen and Nitzany 1966). That effort intensified with the availability of molecular techniques (Kil et al. 2014b; Li et al. 2014; Papayiannis et al. 2011; Salati

Current address for S. Legarrea: EPB-IBED, University of Amsterdam, Amsterdam, The Netherlands. Current address for R. Srinivasan: Department of Entomology, University of Georgia, Griffin, GA 30223.

${ }^{\dagger}$ Corresponding author: R. Srinivasan; babusri@uga.edu

Funding: The authors thank the Georgia Commodity Commission for Vegetables (GACCV) for partially supporting this research.

The author(s) declare no conflict of interest.

Accepted for publication 1 May 2020.

(C) 2020 The American Phytopathological Society et al. 2002). Currently, other crop plants, such as pepper (Kil et al. 2014a; Polston et al. 2006), and several weed species (Salati et al. 2002), such as Datura stramonium L. (Chen et al. 2013a), Lamium amplexicaule L. (Kil et al. 2014b), Stellaria aquatica L. (Moench) (Kil et al. 2015), Solanum nigrum L. (Bedford et al. 1998), and Mercurialis ambigua L. (Sánchez-Campos et al. 2000), are also considered to play a role in the persistence of TYLCV in the agroecosystem.

Like most plant viruses, TYLCV is a vector-borne pathogen (Hogenhout et al. 2008). It is transmitted by the whitefly, Bemisia tabaci (Gennadius), in a circulative and persistent manner. Acquisition of the virus occurs when the insect feeds from the phloem of an infected plant, which can be as short as 15 to $30 \mathrm{~min}$ (Cohen and Nitzany 1966), and the association between the virus and the vector can last during the entire lifespan of the whitefly (Rubinstein and Czosnek 1997). For a plant to be considered a successful TYLCV inoculum source, besides being infected with the virus, it should also permit vector feeding. In addition, if the alternate plant species permits rapid multiplication of the vector, then the alternate plant species could play a critical role in enhancing virus spread (Duffus 1971). As stated above, various reports have described the presence of begomoviruses in wild species or alternate hosts using techniques such as nucleic acid hybridization or polymerase chain reaction (PCR). However, only a few studies have confirmed whether those species can act as inoculum sources and support vector populations through transmission and back-transmission assays (Bedford et al. 1998; Kil et al. 2014a, 2014b, 2015; Polston et al. 2006; Sánchez-Campos et al. 2000). Such information is critical to comprehensively understanding TYLCV epidemics in the landscape. One relevant example is pepper (Capsicum annuum L). Initially, this species was reported to be a dead end for the virus, because whiteflies failed to transmit the virus from pepper to tomato (Morilla et al. 2005). However, there is increasing evidence that whiteflies can transmit the virus from several pepper cultivars (Kil et al. 2014a; Polston et al. 2006). The use of different whitefly cryptic species, pepper genotypes, or experimental conditions may explain the variability in the observed outcomes. Furthermore, the degree of resistance that pepper accessions deploy against the whitefly (Firdaus et al. 2011) might have influenced virus transmission rates. Eggplant (Solanum melongena L.) is another controversial species; it was considered at first to be a nonhost for TYLCV (Czosnek et al. 1993), but relatively recent studies have revealed the presence of the virus in eggplant in several field surveys using detection techniques such as nucleic acid tissue blot 
hybridization (Abou-Jawdah et al. 1999) or PCR followed by sequencing (Kenyon et al. 2014). Eggplant is also well known to be a suitable host to sustain whitefly populations (Shah and Liu 2013). Despite this association, transmission data examining eggplant as an inoculum source for TYLCV are sparse. Palmer amaranth (Amaranthus palmeri S. Watson) is a common species in the southern United States that has become a problematic weed in row crops such as cotton and peanut (Webster and Nichols 2012) as well as in vegetable crops such as tomato and pepper (Webster and MacDonald 2001). Palmer amaranth is highly competitive and has developed resistance against commonly used glyphosatebased herbicides (Wise et al. 2009). Several species of the genus Amaranthus have been shown to be infected with TYLCV around the world (Abou-Jawdah et al. 1999; Güerere et al. 2012; Papayiannis et al. 2011). Recently, Amaranthus retroflexus L. was described as a TYLCV host in Florida (U.S.A.) (Smith et al. 2015).

The agricultural landscape in the state of Georgia (U.S.A.) includes an array of crops from vegetable to row crops (Webster and MacDonald 2001). Tomato is planted in Georgia in a staggered fashion from spring through fall occasionally with a tomato-free period in the summer and always with one in the winter. Other vegetables such as pepper and eggplant are also planted in the same time frame. However, it is not fully understood which alternate hosts (whether crop species or weeds) by acting as green bridges allow for the persistence and annual reoccurrence of TYLCV in the landscape. In addition, TYLCV incidence seems to positively correlate with increasing densities of whiteflies (Anco et al. 2020). Therefore, it is reasonable to presume that common crops and weeds that coexist with tomato could function as virus inoculum sources and whitefly reservoirs. The identification and evaluation of such plant species could be critical to adequately reducing TYLCV-induced disease (Adkins et al. 2011; Smith et al. 2015; Ucko et al. 1998) at the landscape level and to implementing areawide pest management (Anco et al. 2020). In this study, we evaluated the role of three hosts (pepper, eggplant, and Palmer amaranth) as inoculum sources of TYLCV and as reservoirs of whiteflies by performing a series of acquisition and transmission assays with qualitative and quantitative details. Our hypothesis was that these alternate species could serve as virus inoculum sources and would permit virus acquisition by whiteflies and inoculation to tomato.

\section{Materials and Methods}

Plant, insect, and virus materials and maintenance. Eggplant (cultivar Galine F1, Johnny's Seeds, Winslow, ME), pepper (cultivar F1, Harris Moran Seed Company, Sun Prairie, WI), and one widespread weed, Palmer amaranth, were selected for this study. Seeds from Palmer amaranth were collected in 2013 from plants at the Coastal Plain Experiment Station (University of Georgia, Tifton Campus). In addition, a tomato cultivar (Florida 47, Seminis Vegetable Seeds, St. Louis, MO) commonly planted in the region was included. Palmer amaranth was chosen as a potential TYLCV reservoir after a preliminary screening of landscape weeds with potential for virus infection (data not shown). Plants were germinated from seeds and grown in $10 \times 8 \mathrm{~cm}$ plastic pots (Hummert International, Earth City, MO). The potting mixture used for the plants was Sunshine LP5 Plug Mix (Sun Gro Horticulture Industries, Bellevue, WA). Once a week, fertilizer was added to the plants at a concentration of $0.5 \mathrm{~g} /$ liter (water-soluble Miracle-Gro, Scotts Miracle-Gro Products, Marysville, $\mathrm{OH})$. During the entire experimental period, plants were kept in the greenhouse at a photoperiod of $14 \mathrm{~h} / 10 \mathrm{~h}$ (light/dark) and at 25 to $30^{\circ} \mathrm{C}$. Plants of each species were kept in cages $(45 \mathrm{~cm}$ length $\times 45 \mathrm{~cm}$ width $\times 90 \mathrm{~cm}$ height) with a whitefly-proof mesh (MegaView Science, Taichung, Taiwan).

Whiteflies, B. tabaci MEAM1 cryptic species (formerly B biotype), were collected in Tifton, GA, in the fall of 2009 and were reared on cotton plants $(20 \mathrm{~cm}$ tall $)$ in cages with whitefly-proof mesh under the above-stated greenhouse conditions. Cotton was chosen because it is a suitable host plant for B. tabaci (Ahmed et al. 2014) and a reported a nonhost plant for TYLCV (Czosnek et al. 1993; Smith et al. 2015).
The TYLCV-IL isolate was obtained initially from a grower's tomato field in Montezuma, GA, in 2009 (Srinivasan et al. 2012). Since then, TYLCV has been regularly maintained in tomato (cultivar Florida 47) plants inside insect-proof cages under the above-stated conditions via whitefly-mediated inoculations of 4- to 6-week-old tomato seedlings.

Plant inoculation and TYLCV quantitation. Four-week-old plants were inoculated using clip cages $(4 \mathrm{~cm}$ tall $\times 4 \mathrm{~cm}$ diameter $)$ (Muñiz and Nombela 2001) containing 20 viruliferous whiteflies following an acquisition access period (AAP) of $72 \mathrm{~h}$ on symptomatic tomato leaflets (Srinivasan et al. 2012). Subsequently, whiteflies were used to inoculate a group of $\sim 10$ plants for each species (eggplant, pepper, Palmer amaranth, and tomato) by attaching the clip cage to the abaxial side of a young leaf and providing an inoculation access period (IAP) of $72 \mathrm{~h}$ (Fig. 1A) (Srinivasan et al. 2012). Clip cages were removed after $72 \mathrm{~h}$. The experiment was conducted three times to achieve a total of 23 to 30 test plants per species.

Virus infection in inoculated plants was assessed by PCR 4 weeks after inoculation. Four weeks postinoculation is typically sufficient to establish systemic infection and display typical symptoms of infection (Ber et al. 1990; Legarrea et al. 2015; Michelson et al. 1994; Srinivasan et al. 2012). DNA from $100 \mathrm{mg}$ of leaf tissue from the uppermost fully expanded symptomatic leaf tissue was extracted following previously established protocols (Legarrea et al. 2015; Srinivasan et al. 2012). Leaf tissues from the uppermost portion of the plants were selected because prior research has indicated that young leaves accumulate the highest amounts of TYLCV in tomato (Ber et al. 1990). The samples were subsequently flash frozen in liquid nitrogen and processed using a DNeasy plant mini kit (Qiagen, Valencia, CA). The percentage of infected plants of each species was determined by PCR using degenerate begomovirus primers PAL 1v1978/PAR 1c496 (Table 1) (Rojas et al. 1993). The PCR mix included a total volume of $10 \mu \mathrm{l}$ comprising $5 \mu \mathrm{l}$ of GoTaq Green Master Mix (Promega, Madison, WI), $1 \mu \mathrm{l}$ of each forward and reverse primers at a final concentration of $1 \mu \mathrm{M}, 1 \mu \mathrm{l}$ of DNA, and $2 \mu \mathrm{l}$ of nuclease-free $\mathrm{H}_{2} \mathrm{O}$. The conditions of the reaction were an initial denaturation step of $2 \mathrm{~min}$ at $95^{\circ} \mathrm{C}$, followed by 33 cycles of 1 min denaturation at $95^{\circ} \mathrm{C}, 2 \mathrm{~min}$ of annealing at $55^{\circ} \mathrm{C}$, and $2 \mathrm{~min}$ of extension at $72^{\circ} \mathrm{C}$. A final extension step of $10 \mathrm{~min}$ at $72^{\circ} \mathrm{C}$ was included.

To verify that the amplified fragment from the inoculated plant tissue corresponded with the TYLCV isolate used in the experiment, extracted DNA from TYLCV-positive samples was subjected to PCR using the primer pair that targeted a 694-bp C2 region (C21289, C2-1983; Table 1), as described in Legarrea et al. (2015). The resulting amplicons were purified using a QIAquick PCR purification kit (Qiagen) and sequenced (Eurofins MWF Operon, Huntsville, AL) (Legarrea et al. 2015).

Virus copy numbers on TYLCV PCR-positive plants were estimated as previously described (Legarrea et al. 2015). Primers targeting a 102-bp C2 open reading frame (ORF) region (Table 1) were used for TYLCV amplification by real-time PCR (Legarrea et al. 2015). Two technical replicates were included for each sample. Virus copies in tomato and alternate hosts were absolutely quantified by using a standard curve generated from eight 10-fold serial dilutions of a plasmid (pCR2.1-TOPO, Invitrogen, Carlsbad, CA) with a 694-bp C2 insert (C2-1289, C2-1983, Table 1) as outlined in Legarrea et al. (2015).

Whitefly acquisition from alternate species and TYLCV quantitation. To evaluate the ability of whiteflies to acquire TYLCV from infected tomato and alternate hosts, whiteflies were confined to leaves of PCR-positive TYLCV-infected plants of tomato and alternate hosts in clip cages (Muñiz and Nombela 2001) and were provided with an AAP of $72 \mathrm{~h}$. Subsequently, the same whiteflies were transferred to a non-TYLCV host (i.e., cotton, Gossypium hirsutum L.) for an additional period of $72 \mathrm{~h}$ (Fig. 2A) to ensure that the detected TYLCV DNA was located in insect tissues and not transiently present in the gut lumen as a result of feeding on infected plants (Becker et al. 2015; Kollenberg et al. 2014). Following the 72-h feeding period on cotton plants, whiteflies were preserved 
at $-20^{\circ} \mathrm{C}$ until they were processed to evaluate TYLCV infection (Legarrea et al. 2015). In short, each sample consisted of a pool of five insects, and their DNA was extracted using a DNeasy blood and tissue mini kit (Qiagen). This method of extraction employed silica-beads columns (Hajibabaei et al. 2005). By pooling five individuals in this study, an average DNA $( \pm$ SE) yield of $24.3( \pm 2.04)$ $\mathrm{ng} / \mu \mathrm{l}$ was attained. This experiment included three replicates and was conducted three to four times. Therefore, a total of 45 to 60 whiteflies (combined in nine to 12 samples) were processed for each host plant tested. The presence of the virus and viral copy numbers were assessed as in the case of plant samples and per the protocol outlined in Legarrea et al. (2015). Two technical replicates for each sample were included for copy number assessments in quantitative PCR (qPCR).

Back-transmission assays to tomato. Back transmission of TYLCV from three alternate hosts to susceptible recipient tomato (cultivar Florida 47) plants was evaluated. Groups of 20 whiteflies confined in clip cages after an AAP of $72 \mathrm{~h}$ on PCR-positive plants of each alternate species were transferred to susceptible tomato plants (Florida 47) and provided with an IAP of $72 \mathrm{~h}$ (Fig. 3A). Subsequently, a systemic insecticide (thiamethoxam $25 \%$, Actara, Syngenta) was sprayed until runoff at a dosage of 3 oz/acre $(\sim 219 \mathrm{ml} /$ ha), and plants were kept inside insect-proof cages at greenhouse conditions for 4 weeks. Successful back transmission in recipient tomato plants was evaluated visually based on the expression of TYLCV symptoms. Florida 47 is very susceptible to TYLCV and consistently displays characteristic TYLCV symptoms upon infection (Srinivasan et al. 2012). This experiment included at least 10 recipient tomato plants per each alternate host species as an inoculum source. The experiment was conducted three times (total of 29 to 33 recipient tomato plants per each alternate plant species).

Alternate species as hosts for whiteflies. Several whitefly lifetable parameters (developmental time, juvenile survival, and oviposition) were evaluated on three alternate hosts in comparison with tomato. For this purpose, four plants per each plant species were kept in a growth chamber (Percival, Perry, IA) at $26 \pm 3^{\circ} \mathrm{C}$ (mean \pm $\mathrm{SD}$ ) with 14-h/10-h (light/dark) photoperiod. Three clip cages containing five adult females were attached to the abaxial side of a leaf on each plant, allowing an oviposition period of $48 \mathrm{~h}$. Recently emerged females from the laboratory stock colony reared on cotton were selected for this purpose. Once adult whiteflies and cages were removed, oviposition was estimated by counting the number of eggs laid on the leaf. Subsequently, six eggs in each cage were randomly selected and monitored daily for juvenile survival until adult emergence. Thus, the developmental time from egg to adult of $B$. tabaci was studied in a total of 66 to 72 individuals per species.

Throughout the course of this study, upon completion, TYLCVinfected plant material or viruliferous whiteflies from all experiments were disposed of according to the University of Georgia "Environmental Health \& Safety Management System" code of conduct. All live materials including plants and whiteflies were frozen at $-20^{\circ} \mathrm{C}$ for at least $48 \mathrm{~h}$ prior to autoclaving and disposal.

Statistical analysis. Statistical analysis was performed in SAS Enterprise 4.2 (SAS Institute, Cary, NC). Percent infection data in plants and whiteflies were analyzed using logistic regression through the PROC GENMOD option in SAS assuming a binomial response (presence or absence of TYLCV infection). Other response variables (accumulation of viral DNA in the plant or in the whitefly, whitefly development, and whitefly oviposition) were analyzed using generalized linear mixed model through the PROC GLIMMIX option in SAS. For qPCR data, the average value of the two technical replicates performed in the reaction was used. Treatments were considered as fixed effects and replications as random effects. Treatment means that resulted in statistical differences were separated by using pairwise orthogonal contrasts or the Tukey-Kramer test. In addition, the median time required for whiteflies to reach adult stage was

A
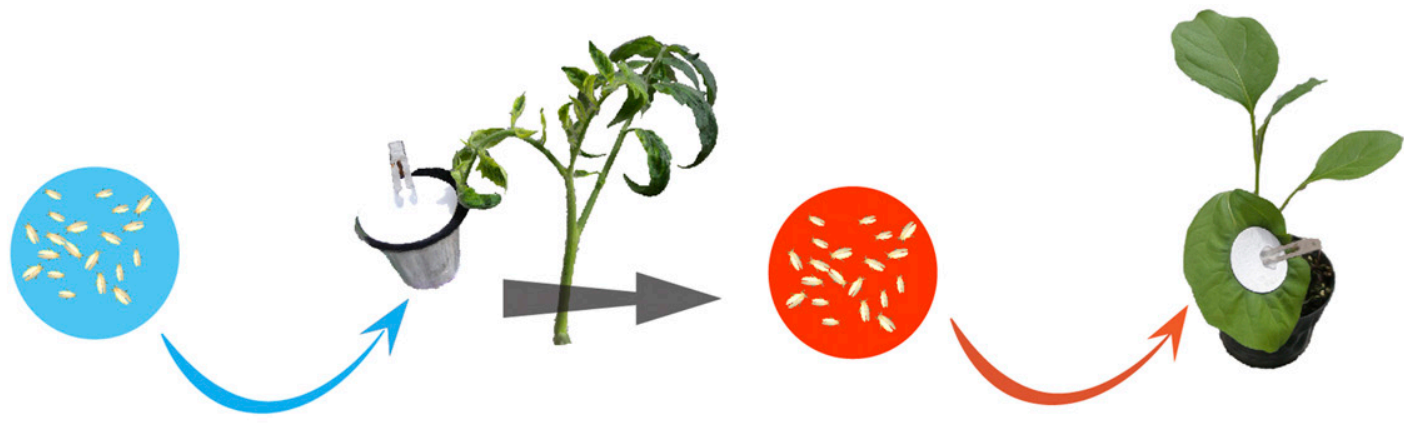

72h AAP on infected tomato

72h IAP on alternate plants

B

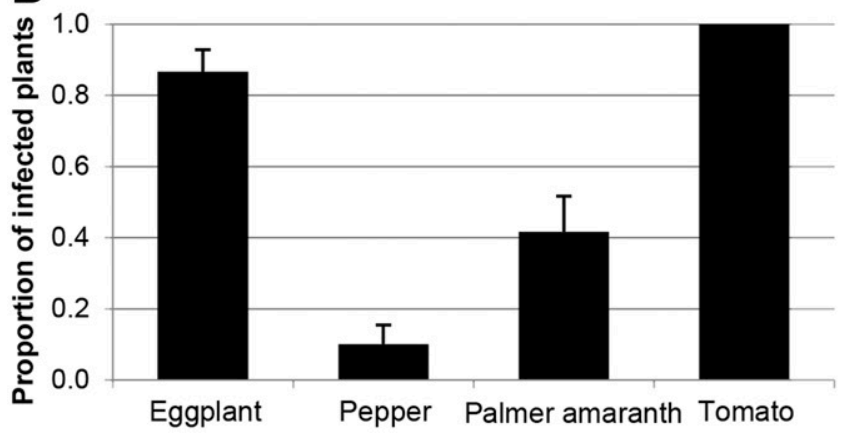

C

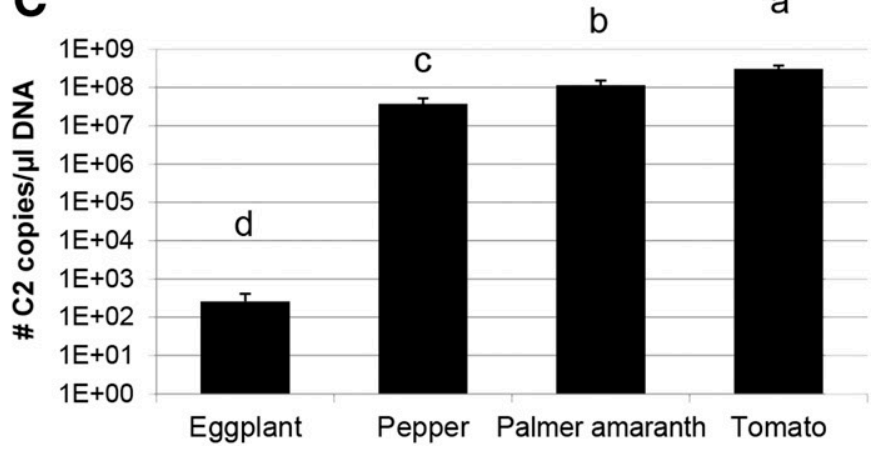

Fig. 1. Tomato yellow leaf curl virus (TYLCV) inoculation of alternate species. A, Diagram of the protocol for TYLCV inoculation of alternate species. Whiteflies confined in a clip cage were attached to an infected plant for an acquisition access period (AAP) of $72 \mathrm{~h}$ and then transferred to a recipient plant for an inoculation access period (IAP) of $72 \mathrm{~h}$. B, Percentage of infected plants based on PCR detection (primer pair 1, Table 1). C, Accumulation of TYLCV copies on infected alternate plants as estimated by qPCR (primer pair 2 , Table 1). Viral copies in TYLCV-infected samples were assessed by qPCR via absolute quantitation. Different letters indicate significant differences (LSD, $P=0.05)$, and error bars represent the SE of the mean. 
analyzed by a median one-way ANOVA, a nonparametric test using PROC NONPAR1WAY in SAS. In all cases, the significance level of the tests was set at $95 \%$.

\section{Results}

Plant inoculation and TYLCV quantitation. Whitefly-mediated inoculation of TYLCV resulted in infection in all species tested with only tomato displaying infection symptoms such as yellowing, leaf curling, and stunting. PCR amplicons (Fig. 4) corresponding to all plant species tested were sequenced, and the sequences were identical among samples from different species. ClustalW (Thompson et al. 1994) sequence analysis for multiple alignment showed $>99 \%$ sequence identity with the C2 ORF of a TYLCV reference isolate from our laboratory already deposited in GenBank (KY971370.1). This result confirms the ability of whiteflies to transmit TYLCV to eggplant, pepper, and Palmer amaranth even though transmission percentages varied among species when compared with tomato $\left(\chi^{2}=43.48, \mathrm{df}=3,82, P<0.0001\right)$. Results revealed that the percentage of TYLCV infection was higher in tomato and eggplant than in Palmer amaranth and pepper, and the infection percentage in Palmer amaranth was higher than in pepper (Fig. 1B, Table 2).
The accumulation of TYLCV was evaluated on those plants that tested positive by PCR (Fig. 1C). The quantity of viral copies accumulated in the plants significantly differed among species $(F=$ infinity, $\mathrm{df}=3,48, P<0.0001)$. Eggplant had the lowest number of viral copies $(255 \pm 153$; mean $\pm \mathrm{SE})$, whereas the highest number of copies was observed in tomato samples $\left(3.07 \times 10^{8} \pm 6.50 \times 10^{7} \mathrm{copies} / \mu \mathrm{l}\right.$ of DNA). Both pepper $\left(3.69 \times 10^{7} \pm 1.54 \times 10^{7}\right.$ copies/ $\mu 1$ of DNA $)$ and Palmer amaranth $\left(1.14 \times 10^{8} \pm 3.71 \times 10^{7}\right.$ copies $/ \mu l$ of DNA $)$ plants had intermediate amounts of viral copies and were significantly different between each other (Fig. 1C).

Whitefly acquisition from alternate species and TYLCV quantitation. TYLCV was successfully detected in whiteflies that fed on infected plants in a substantial percentage of samples, indicating that whiteflies effectively acquired the virus after a 72-h AAP from all four plant hosts (Fig. 2B, Table 3). Significant differences were identified in the percentages of TYLCV acquisition in whiteflies following an AAP on four plant species tested: eggplant, pepper, Palmer amaranth, and tomato $\left(\chi^{2}=10.46, \mathrm{df}=3,41, P=0.0156\right)$. Percentage of TYLCV acquisition in whiteflies was higher following an AAP on tomato and Palmer amaranth than on pepper and eggplant. TYLCV accumulation levels in whiteflies also

Table 1. Primers employed in PCR

\begin{tabular}{|c|c|c|c|c|c|c|}
\hline Pair & Name & Sequence $\left(5^{\prime}-3^{\prime}\right)$ & nt & Target gene & Product size (nt) & Reaction type \\
\hline \multirow[t]{2}{*}{$\overline{1^{z}}$} & PAL 1v1978 & CGATCTGCAGGCCCACATYGTCTTYCCNGT & 30 & ORI & 1,400 & PCR \\
\hline & PAR $1 \mathrm{c} 496$ & AATACTGCAGGGCTTYCTRTACATRGG & 27 & & & \\
\hline \multirow[t]{2}{*}{2} & TYLC-C2-For & GCAGTGATGAGTTCCCCTGT & 20 & $\mathrm{C} 2 \mathrm{ORF}$ & 102 & qPCR \\
\hline & TYLC-C2-Rev & CCAATAAGGCGTAAGCGTGT & 20 & & & \\
\hline \multirow[t]{2}{*}{3} & $\mathrm{C} 2-1289$ & CATGATCCACTGCTCTGATTACA & 23 & $\mathrm{C} 2 \mathrm{ORF}$ & 694 & PCR \\
\hline & C2-1983 & TCATTGATGACGTAGACCCG & 20 & & & \\
\hline
\end{tabular}

z Primer pair designed in Rojas et al. (1993).

A

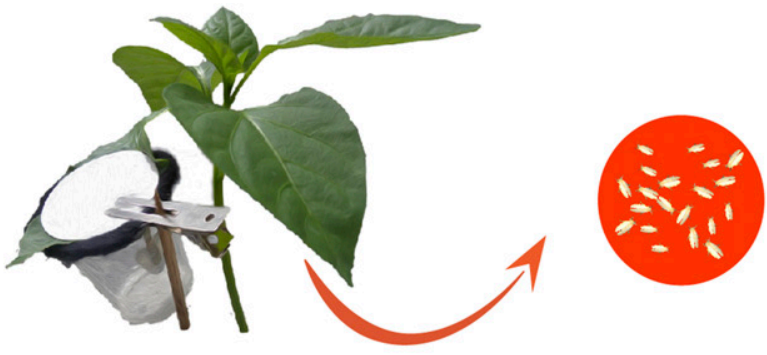

72h AAP on infected aternate plant

B

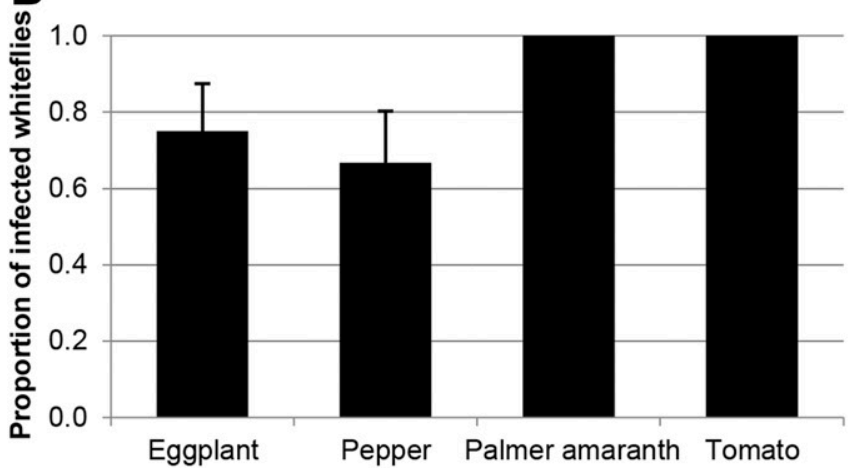

C

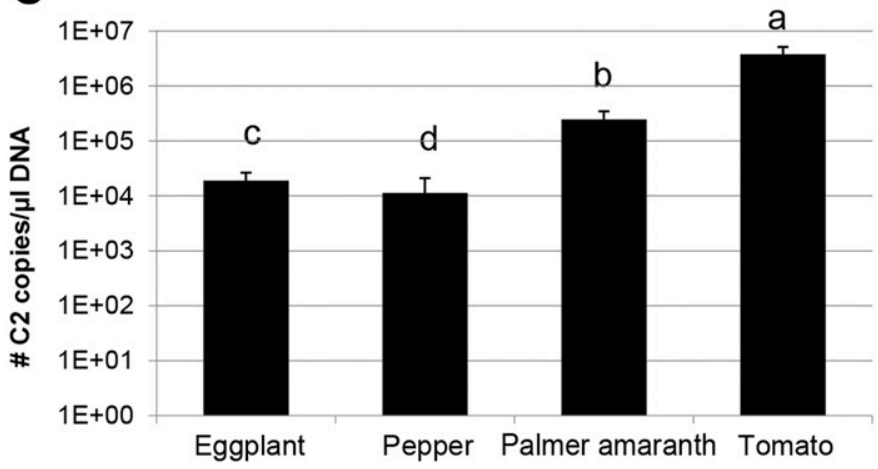

Fig. 2. Acquisition of tomato yellow leaf curl virus (TYLCV) by whiteflies from alternate species. A, Diagram showing the protocol for testing virus acquisition from alternate hosts infected with TYLCV on which whiteflies were confined to clip cages and were given an acquisition access period (AAP) of $72 \mathrm{~h}$. B, Percentage of samples (mean \pm SE) that included infected whiteflies after an acquisition access period of $72 \mathrm{~h}$ based on detection by PCR (primer pair 1, Table 1). C, Accumulation of TYLCV DNA copies on whitefly samples based on qPCR (primer pair 2, Table 1). Viral copies in whitefly samples were assessed by qPCR via absolute quantitation. Different letters indicate significant differences (LSD, $P=0.05$ ), and error bars represent the SE of the mean. 
substantially varied among plant species ( $F=$ infinity, $\mathrm{df}=3,35, P<$ 0.0001 , Fig. 2C). The highest number of TYLCV copies accumulated in whiteflies that acquired the virus from tomato plants $\left(3.77 \times 10^{6} \pm 1.36 \times 10^{6} \mathrm{TYLCV}\right.$ copies/ $\mu$ l of DNA, mean $\left.\pm \mathrm{SE}\right)$.
Whiteflies feeding on alternate species accumulated significantly fewer copies of TYLCV than from tomato. When Palmer amaranth was a source for acquisition, whiteflies acquired one order of magnitude less than from tomato $\left(2.46 \times 10^{5} \pm 1.02 \times 10^{5}\right.$ TYLCV

\section{A}

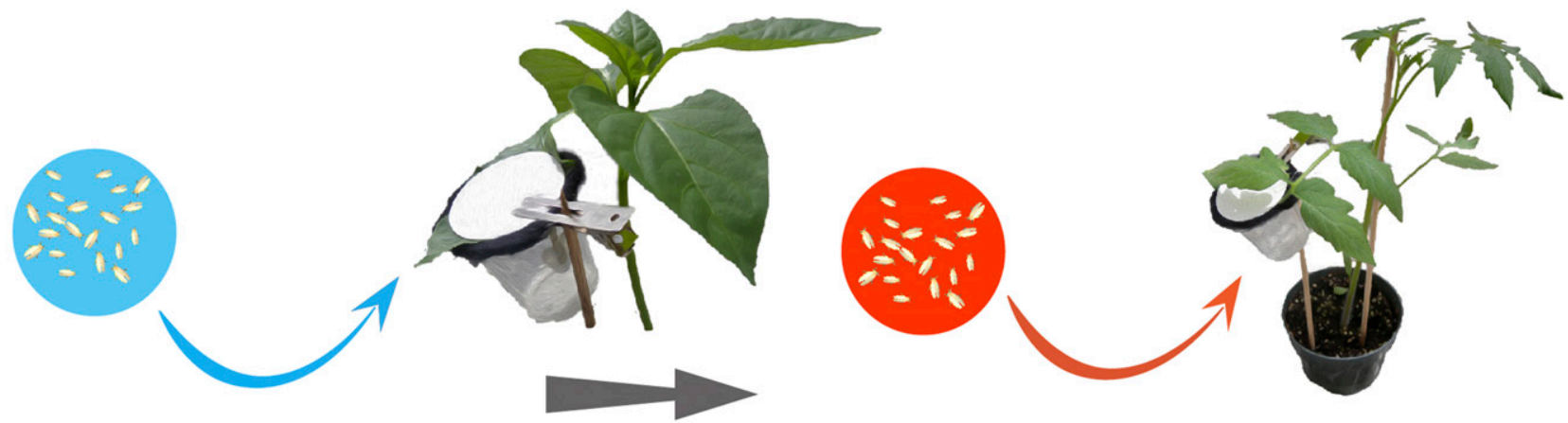

72h AAP on infected alternate plant

72h IAP on tomato

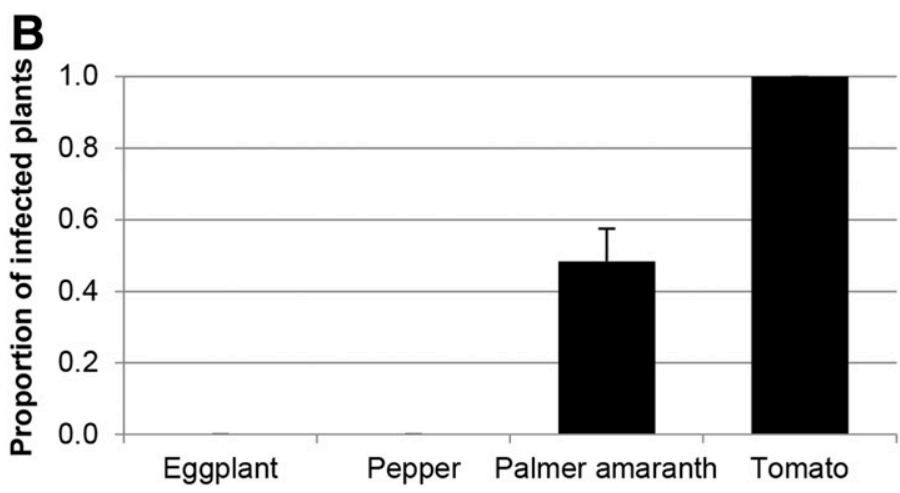

Fig. 3. Tomato yellow leaf curl virus (TYLCV) back-transmission assays from alternate species. A, Diagram showing the protocol to test whether alternate species are a source for TYLCV inoculum. Whiteflies were given an acquisition access period (AAP) of $72 \mathrm{~h}$ on infected plants and an inoculation access period (IAP) of $72 \mathrm{~h}$ on susceptible tomato plants. $B$, Percentage of TYLCV infection in back-transmission assays based on visual symptoms in tomato plants. Different letters indicate significant differences (LSD, $P=0.05$ ), and error bars represent the SE of the mean.

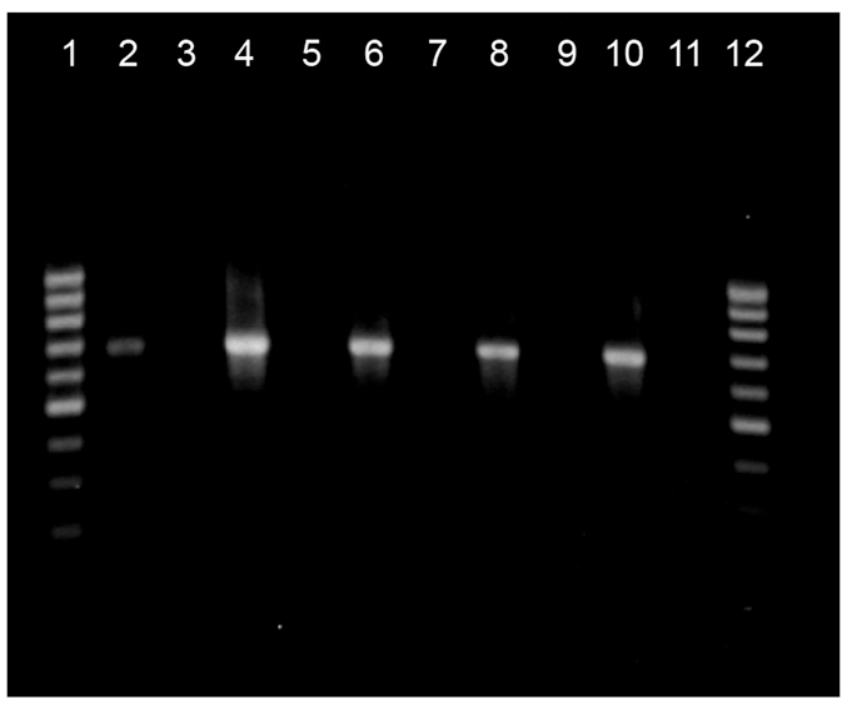

Fig. 4. Agarose gel (1\%) showing amplicons of tomato yellow leaf curl virus DNA at the expected size ( $690 \mathrm{nt})$ amplified in the C2 ORF from several plant species that were inoculated with whiteflies (primer pair 3, Table 1). Lanes 1 and 12 correspond to 100bp ladder. The codes for the identification of samples in the lanes are as follows: $2=$ infected eggplant; $3=$ noninfected eggplant; $4=$ infected Palmer amaranth; $5=$ noninfected Palmer amaranth; $6=$ infected pepper; $7=$ noninfected pepper; $8=$ infected tomato; $9=$ noninfected tomato; $10=$ positive control from DNA extracted from a symptomatic tomato plant; and $11=$ water negative control.
Table 2. Tomato yellow leaf curl virus infection in tomato and alternate hosts following whitefly-mediated transmission

\begin{tabular}{lcrr}
\hline Source & df & \multicolumn{1}{c}{$\boldsymbol{\chi}^{\mathbf{2}}$} & $\boldsymbol{P}>\boldsymbol{\chi}^{\mathbf{2}}$ \\
\hline Plant species & 3 & 43.48 & $<0.0001$ \\
Plant species contrasts & & & \\
$\quad$ Eggplant versus pepper & 1 & 38.92 & $<0.0001$ \\
$\quad$ Eggplant versus Palmer amaranth & 1 & 11.46 & 0.0007 \\
Eggplant versus tomato & 1 & 0.82 & 0.3665 \\
Pepper versus Palmer amaranth & 1 & 7.70 & 0.0055 \\
Pepper versus tomato & 1 & 11.59 & 0.0007 \\
Tomato versus Palmer amaranth & 1 & 4.55 & 0.0329 \\
\hline
\end{tabular}

Table 3. Tomato yellow leaf curl virus acquisition by whiteflies following an acquisition access period on tomato and alternate hosts

\begin{tabular}{lccc}
\hline Source & df & $\boldsymbol{\chi}^{\mathbf{2}}$ & $\boldsymbol{P}>\boldsymbol{\chi}^{\mathbf{2}}$ \\
\hline Plant species & 3 & 10.46 & 0.0150 \\
Plant species contrasts & & & \\
$\quad$ Eggplant versus pepper & 1 & 0.20 & 0.6529 \\
Eggplant versus Palmer amaranth & 1 & 4.59 & 0.0322 \\
$\quad$ Eggplant versus tomato & 1 & 4.03 & 0.0447 \\
Pepper versus Palmer amaranth & 1 & 6.35 & 0.0117 \\
$\quad$ Pepper versus tomato & 1 & 5.59 & 0.0181 \\
$\quad$ Tomato versus Palmer amaranth & 1 & 0.00 & 1.0000 \\
\hline
\end{tabular}


copies/ $\mu$ l of DNA). The difference was two orders of magnitude lower than tomato when whiteflies acquired TYLCV from infected eggplant $\left(1.89 \times 10^{4} \pm 7.55 \times 10^{3}\right.$ TYLCV copies/ $\mu 1$ of DNA $)$ and pepper $\left(1.13 \times 10^{4} \pm 9.52 \times 10^{3} \mathrm{TYLCV}\right.$ copies/ $\mu$ l of DNA $)$.

Back-transmission assays to tomato. Results form the backtransmission assays performed with TYLCV-infected alternate species and tomato as inoculum sources and tomato as recipients revealed that only Palmer amaranth and tomato were effective as inoculum sources for the virus (Fig. 3B, Table 4). However, the transmission percentage from Palmer amaranth to tomato was only half of that achieved following back-transmission assay from tomato to tomato $\left(\chi^{2}=97.44, \mathrm{df}=3,106, P<0.0001\right)$. TYLCV transmission to tomato was not observed after a 72-h AAP on TYLCV-infected eggplant and pepper.

Alternate species as hosts for whiteflies. The capability of the selected plant species to act as a suitable host for B. tabaci was tested by evaluating three life-table parameters: nymphal survival, developmental time, and fecundity over a 2-day period. The time required by $B$. tabaci to reach adulthood from egg was significantly different on the host species tested $\left(\chi^{2}=23.35, \mathrm{df}=3,219, P<0.0001\right)$. The developmental time was shorter on eggplant when compared with the other three plant species (Table 5). Furthermore, nymphal survival was over $90 \%$ on eggplant, Palmer amaranth, and tomato (Fig. 5A). However, significant differences were found when the three species were compared with whiteflies that developed on pepper ( $F=70.037$, df $=3,43, P<0.0001)$. In fact, whiteflies' survival was reduced to only $30 \%$ on pepper plants.

There were significant differences in the number of eggs laid depending on the plant species they were exposed to $(F=9.74$, df $=3,41, P<0.0001$ ) (Fig. 5B). The lowest oviposition was observed on Palmer amaranth with approximately one egg per female per day, which was about seven times lower than on eggplant. Whiteflies' egg production per female per day was five and three on tomato and pepper, respectively. Significant differences based on the TukeyKramer grouping were only found between the following combinations: tomato and Palmer amaranth, eggplant and pepper, and eggplant and Palmer amaranth (Fig. 5B).

Table 4. Tomato yellow leaf curl virus (TYLCV) infection in recipient tomato plants following back transmission of TYLCV from alternate hosts

\begin{tabular}{lccc}
\hline Source & df & $\boldsymbol{\chi}^{\mathbf{2}}$ & \multicolumn{1}{c}{$\boldsymbol{P}>\boldsymbol{\chi}^{\mathbf{2}}$} \\
\hline Plant species & 3 & 97.44 & $<0.0001$ \\
Plant species contrasts & & & \\
$\quad$ Eggplant versus pepper & 1 & 0.00 & 1.0000 \\
Eggplant versus Palmer amaranth & 1 & 24.49 & $<0.0001$ \\
Eggplant versus tomato & 1 & 69.10 & $<0.0001$ \\
Pepper versus Palmer amaranth & 1 & 24.49 & $<0.0001$ \\
Pepper versus tomato & 1 & 69.10 & $<0.0001$ \\
$\quad$ Tomato versus Palmer amaranth & 1 & 20.92 & $<0.0001$ \\
\hline
\end{tabular}

\section{Discussion}

The role of an alternate host as a reservoir for a given plant virus is not only conditioned by the capability of the pathogen to infect that species but also by the adequate interaction between that plant and the insect vector that leads to a successful virus acquisition and inoculation (Duffus 1971). In this study, we demonstrated that different plant species vary in the amount of virus they accumulate and in their ability to sustain the population of the insect vector. The combination of these two factors will likely determine the contribution of this alternate plant species to virus spread in the landscape.

For instance, pepper tested positive in numerous TYLCV alternate host surveys (Hernández-Espinal et al. 2018; Polston et al. 2006; Salati et al. 2002; Shirazi et al. 2014). In this study, pepper plants were infected with TYLCV following whitefly-mediated inoculation, albeit the infection percentage was low. Also, TYLCV accumulation in pepper was lower than in tomato. Contrary to previous studies (Kil et al. 2014a; Polston et al. 2006), TYLCV from pepper was not back transmitted to tomato in this study, probably because the pepper cultivar used in this study was not a suitable host for the cryptic species $B$. tabaci MEAM1 (biotype B), thereby limiting its ability to feed and inoculate TYLCV during the 72-h IAP. Firdaus et al. (2011) reported a high variability in resistance among pepper genotypes to whiteflies, in which whitefly oviposition rates ranged from 1.3 to 5.6 eggs/day and nymphal survival proportions ranged from 0.1 to 1 . Based on that assessment, the pepper cultivar used in this study (Magico F1) could be ranked as a moderately resistant genotype with high nymphal mortality $(\sim 70 \%)$ and a relatively low oviposition rate $(2.7 \mathrm{eggs} / \mathrm{female} /$ day). Perhaps this intraspecific variation in resistance against whiteflies could reflect why the consideration of pepper as a susceptible host of TYLCV varies largely with the cultivar chosen for the experiment (Kil et al. 2014a; Polston et al. 2006). Additionally, the whitefly biotype used could be a major determinant of the outcome of the resistance status of the pepper genotype. Even though antibiosis-based resistance has been reported in several pepper cultivars, the effect seems to be specific against the MEAM1 cryptic species (B biotype) of $B$. tabaci but not effective against the MED cryptic species (Q biotype) (Jiao et al. 2014; Lorenzo et al. 2016). Therefore, pepper may function as a host for TYLCV, but its ability to influence TYLCV epidemics may depend on the cultivar's ability to support whitefly populations.

A high proportion of inoculated eggplants was infected with TYLCV. Despite systemic infection, qPCR analysis revealed that eggplant harbored a very low level of the virus (six orders of magnitude less than tomato) following infection. The mechanisms that lead to lower accumulation in eggplant when compared with tomato are unknown. An earlier study using agro-inoculated eggplant leaf discs points to the lack of TYLCV replication as mechanism of resistance in eggplant (Czosnek et al. 1993). Also, TYLCV replication in eggplants could be influenced by the activation of plant defenses (Chen et al. 2013b; Garcia-Ruiz 2019; Gorovits et al. 2016; Haxim et al. 2017).

Table 5. Developmental time of whiteflies on different plant species

\begin{tabular}{lccccc}
\hline Plant hosts & $\boldsymbol{N}^{\mathbf{x}}$ & Egg to adult $^{\mathbf{y}}$ & Sum of scores $^{\mathbf{z}}$ & ${\text { Expected under } \mathbf{H}_{\mathbf{0}}^{\mathbf{z}}}^{\mathbf{z}}$ & ${\text { Standard deviation under } \mathbf{H}_{\mathbf{0}}^{\mathbf{z}}}^{\text {Mean score }^{\mathbf{z}}}$ \\
\hline Eggplant & 71 & $19(17-25) \mathrm{a}$ & 19.20 & 35.34 & 3.40 \\
Pepper & 23 & $21(18-28) \mathrm{b}$ & 12.52 & 11.49 & 0.27 \\
Palmer amaranth & 64 & $21(17-29) \mathrm{b}$ & 37.60 & 31.86 & 3.22 \\
Tomato & 65 & $22(18-30) \mathrm{b}$ & 41.67 & 32.35 & 3.31 \\
Test statistics & & & & & 0.59 \\
$\chi^{2}=23.35$ & & & & \\
df $=3,219$ & & & & \\
$P<0.0001$ & & & & & \\
\end{tabular}

${ }^{x}$ Number of individual eggs monitored to adulthood on tomato and alternate hosts.

y Median development time from egg to adult on each plant host with range in parenthesis. Different letters indicate significant differences in developmental time between plant hosts.

${ }^{\mathrm{z}}$ Sum of scores for median one-way analysis, sum of scores expected under null hypothesis that developmental time in tomato and alternate hosts is not different, standard deviation from null hypothesis, and mean scores. 
Following lower TYLCV accumulation in eggplant, whiteflies acquired lower amounts of TYLCV DNA from eggplant than from other hosts evaluated in this study. Acquisition of viruses by B. tabaci has been previously shown to correlate with the amount of virus available in their host plants (Kollenberg et al. 2014; Lapidot et al. 2001; Legarrea et al. 2015; Wintermantel et al. 2008). Interestingly, the amount of TYLCV copies per unit of isolated DNA was higher for whiteflies feeding on eggplant than the accumulation in plants themselves. It is possible that continuous whitefly feeding from the phloem and acquisition over the period of $72 \mathrm{~h}$ resulted in a higher concentration of the virus in the insect than in the plant. Becker et al. (2015) showed that exposure of whiteflies to TYLCV-infected tomato for $48 \mathrm{~h}$ led to an exponential accumulation of the virus, which was kept almost constant for the following 20 days after feeding on a non-TYLCV host plant. The lower accumulation of TYLCV in the insect vector feeding from eggplant compared with other plant species might compromise the role of eggplant as an inoculum source. In contrast, eggplant is a suitable host for the vector, as demonstrated in this and another study (Shah and Liu 2013). Eggplant may consequently play a role in increasing the whitefly population buildup in the landscape and indirectly contribute to TYLCV epidemics.

In contrast, Palmer amaranth, when compared with eggplant and pepper, might play a critical role in the persistence of TYLCV in the landscape. Even though this species was not a highly suitable host for B. tabaci (based on the low oviposition following confinement in clip cages), there was no noticeable evidence for antibiosis against whiteflies. Immature mortality was lower in Palmer amaranth than in eggplant or pepper, and there was no delay in developmental time when compared with tomato. In addition, there was substantial whitefly-mediated inoculation of the virus to Palmer amaranth, and the virus accumulated to higher levels in Palmer amaranth than in eggplant and pepper but lower than tomato. This highlights the risk that this species poses in maintaining TYLCV inoculum in the landscape. Although some Palmer amaranth plants may overwinter, it is generally considered as an annual plant that grows during the
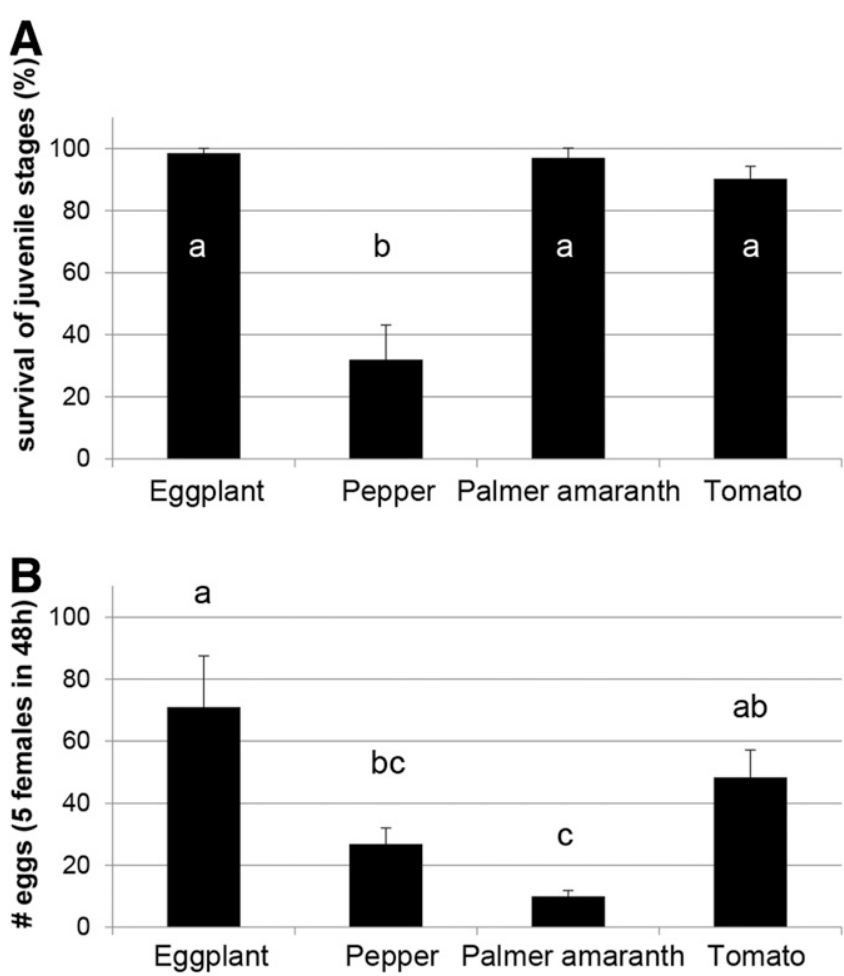

Fig. 5. Whitefly developmental parameters of Bemisia tabaci on eggplant, pepper, Palmer amaranth, and tomato. A, Percentage of whitefly eggs that survived to adulthood. B, Average oviposition of five female whiteflies in a clip cage attached to the plant for $48 \mathrm{~h}$. Different letters indicate significant differences (LSD, $P=0.05$ ). Error bars refer to the SE of the mean. summer cycle (Davis et al. 2015). Therefore, it will most likely play a role as a green bridge between crops rather than as an overwintering reservoir. In any case, it would be advisable to adequately manage this species in the landscape. This, however, might be challenging, because this species is invasive in numerous crop fields including vegetables in the southeastern region of the United States (Webster and MacDonald 2001), and it has developed resistance against a variety of herbicides (Wise et al. 2009).

The aim of this study was to explore the potential role of several species aside from tomato, as hosts for TYLCV and its vector $B$. tabaci. An additional factor that may play a relevant role in modulating virus-vector interaction is the infection status of the host plant. It is well known that TYLCV modifies several phenotypic traits in plants such as the volatile profile displayed (Fang et al. 2013), plant defense responses, and other traits that modulate plant-insect interactions ( $\mathrm{Su}$ et al. 2015). In most cases, such changes are predicted to increase virus fitness by manipulating vector behavior (Fang et al. 2013). Indeed, TYLCV infection in another weed species (D. stramonium) induced changes in the plant that led to increased attraction of whiteflies and enhanced development of whiteflies (Chen et al. 2013a). Future studies could incorporate this dimension for the alternate host species described here to unravel whether, for example, infection by TYLCV may transform pepper plants into a better host plant for the whitefly by increasing immature survival. Such an effect might alter the prominence of pepper plants in TYLCV epidemics relative to what is acknowledged in this work.

Analyzing virus accumulation in all three species suggests that there could be thresholds for virus acquisition and inoculation associated with those species. Threshold levels were first envisioned when reduced levels of TYLCV accumulated in a partially resistant tomato genotype relative to a susceptible genotype. However, backtransmission percentages did not vary between susceptible and resistant genotypes (Lapidot et al. 2001). It is possible virus acquisition by whiteflies from susceptible and resistant genotypes was above the hypothetical threshold required for efficient transmission. Another study demonstrated that whiteflies acquired fewer viral copies from TYLCV-resistant plants when compared with a TYLCVsusceptible genotype (Legarrea et al. 2015), and transmission percentages also varied among the different resistant genotypes (Srinivasan et al. 2012), suggesting that sufficient viral copies necessary to initiate infection were not acquired from some resistant genotypes. The current study also seems to provide further evidence to support the existence of such transmission thresholds. First, even though the levels of TYLCV in eggplant were detectable by PCR, the viral loads that the whiteflies acquired were below a hypothetical transmission threshold, because no back transmission occurred from these infected plants. Second, pepper plants accumulated substantially higher levels of TYLCV than eggplant in their tissue; however, effects on whitefly biology and/or feeding could have prevented virus acquisition beyond the threshold required for a successful inoculation of a recipient host. Third, the accumulation of TYLCV in Palmer amaranth plants and in the whiteflies feeding on them was sufficient to inoculate the virus to recipient tomato plants. Further studies could focus on quantifying the number of viral copies present in whiteflies from field samples, correlate their viral load with their ability to transmit TYLCV, and corroborate the existence of transmission thresholds.

Overall, this study demonstrates that in order to play a major role in epidemics, an infected plant should both accumulate sufficient levels of TYLCV and adequately interact with the whiteflies to facilitate virus transmission. Widely prevalent alternate hosts such as Palmer amaranth in the landscape of the southeastern United States may facilitate the persistence of TYLCV. Understanding the interactions between TYLCV and whiteflies and alternate hosts could be exploited in the future for effective yellow leaf curl disease management in tomato at the landscape level.

\section{Acknowledgments}

We are grateful to Simmy Mckeown, Sheran Thompson, and Julia Kitchens for their technical assistance rendered during this study. We thank three anonymous reviewers for their useful comments on the previous versions of this manuscript. 


\section{Literature Cited}

Abou-Jawdah, Y., Maalouf, R., Shebaro, W., and Soubra, K. 1999. Comparison of the reaction of tomato lines to infection by tomato yellow leaf curl begomovirus in Lebanon. Plant Pathol. 48:727-734.

Adkins, S., Webster, C. G., Kousik, C. S., Webb, S. E., Roberts, P. D., Stansly, P. A., and Turechek, W. W. 2011. Ecology and management of whiteflytransmitted viruses of vegetable crops in Florida. Virus Res. 159:110-114.

Ahmed, M. Z., Naveed, M., Noor ul Ane, M., Ren, S. X., De Barro, P., and Qiu, B. L. 2014. Host suitability comparison between the MEAM1 and AsiaII 1 cryptic species of Bemisia tabaci in cotton-growing zones of Pakistan. Pest Mgmt. Sci. 70:1531-1537.

Alexander, H. M., Mauck, K. E., Whitfield, A. E., Garrett, K. A., and Malmstrom, C. M. 2014. Plant-virus interactions and the agro-ecological interface. Eur. J. Plant Pathol. 138:529-547.

Anco, D. J., Rouse, L., Lucas, L., Parks, F., Mellinger, H. C., Adkins, S., Kousik, C. S., Stansly, P. A., Ha, M., and Turechek, W. W. 2020. Spatial and temporal physiognomies of whitefly and tomato yellow leaf curl virus epidemics in southwestern Florida tomato fields. Phytopathology 110:130-145.

Becker, N., Rimbaud, L., Chiroleu, F., Reynaud, B., Thébaud, G., and Lett, J. M. 2015. Rapid accumulation and low degradation: Key parameters of tomato yellow leaf curl virus persistence in its insect vector Bemisia tabaci. Sci. Rep. 5:17696.

Bedford, I. D., Kelly, A., Banks, G. K., Briddon, R. W., Cenis, J. L., and Markham, P. G. 1998. Solanum nigrum: An indigenous weed reservoir for a tomato yellow leaf curl geminivirus in southern Spain. Eur. J. Plant Pathol. 104:221-222.

Ber, R., Navot, N., Zamir, D., Antignus, Y., Cohen, S., and Czosnek, H. 1990. Infection of tomato by the tomato yellow leaf curl virus: Susceptibility to infection, symptom development, and accumulation of viral DNA. Arch. Virol. 112:169-180.

Chen, G., Pan, H., Xie, W., Wang, S., Wu, Q., Fang, Y., Shi, X., and Zhang, Y. 2013a. Virus infection of a weed increases vector attraction to and vector fitness on the weed. Sci. Rep. 3:2253

Chen, T., Lv, Y., Zhao, T., Li, N., Yang, Y., Yu, W., He, X., Liu, T., and Zhang, B. 2013b. Comparative transcriptome profiling of a resistant vs. susceptible tomato (Solanum lycopersicum) cultivar in response to infection by tomato yellow leaf curl virus. PLoS One 8:e80816.

Cohen, S., and Nitzany, F. E. 1966. Transmission and host range of the tomato yellow leaf curl virus. Phytopathology 56:1127-1131.

Czosnek, H., Kheyr-Pour, A., Gronenborn, B., Remetz, E., Zeidan, M., Altman, A., Rabinowitch, H. D., Vidavsky, S., Kedar, N., Gafni, Y., and Zamir, D. 1993. Replication of tomato yellow leaf curl virus (TYLCV) DNA in agroinoculated leaf discs from selected tomato genotypes. Plant Mol. Biol. 22:995-1005.

Davis, A. S., Schutte, B. J., Hager, A. G., and Young, B. G. 2015. Palmer amaranth (Amaranthus palmeri) damage niche in Illinois soybean is seed limited. Weed Sci. 63:658-668.

Duffus, J. E. 1971. Role of weeds in the incidence of virus diseases. Annu. Rev. Phytopathol. 9:319-340.

Fang, Y., Jiao, X., Xie, W., Wang, S., Wu, Q., Shi, X., Chen, G., Su, Q., Yang, X., Pan, H., and Zhang, Y. 2013. Tomato yellow leaf curl virus alters the host preferences of its vector Bemisia tabaci. Sci. Rep. 3:2876.

Firdaus, S., Van Heusden, A., Harpenas, A., Supena, E. D. J., Visser, R. G. F., and Vosman, B. 2011. Identification of silverleaf whitefly resistance in pepper. Plant Breed. 130:708-714.

Garcia-Ruiz, H. 2019. Host factors against plant viruses. Mol. Plant Pathol. 20: 1588-1601.

Gorovits, R., Fridman, L., Kolot, M., Rotem, O., Ghanim, M., Shriki, O., and Czosnek, H. 2016. Tomato yellow leaf curl virus confronts host degradation by sheltering in small/midsized protein aggregates. Virus Res. 213:304-313.

Güerere, P., Chirinos, D. T., Geraud-Pouey, F., Moriones, E., Santana, M. A., Franco, M. A., Galindo-Castro, I., and Romay, G. 2012. Experimental transmission of the mild strain of tomato yellow leaf curl virus (TYLCV) to Amaranthus dubius by Bemisia tabaci. Phytoparasitica 40:369-373.

Hajibabaei, M., deWaard, J. R., Ivanova, N. V., Ratnasingham, S., Dooh, R. T., Kirk, S. L., Mackie, P. M., and Hebert, P. D. 2005. Critical factors for assembling a high volume of DNA barcodes. Philos. Trans. R. Soc. Lond. B Biol. Sci. 360:1959-1967.

Haxim, Y., Ismayil, A., Jia, Q., Wang, Y., Zheng, X., Chen, T., Qian, L., Liu, N., Wang, Y., Han, S., Cheng, J., Qi, Y., and Liu, Y. 2017. Autophagy functions as an antiviral mechanism against geminiviruses in plants. eLife 6:e23897.

Hernández-Espinal, L. A., Enríquez-Verdugo, I., Melgoza-Villagómez, C. M., RetesManjarrez, J. E., Velarde-Félix, S., Linares-Flores, P. J., and Garzón-Tiznado, J. A. 2018. Phylogenetic analysis and distribution of begomovirus in pepper (Capsicum annuum L.) crop in Sinaloa, Mexico. Rev. Fitotec. Mex. 41:149-157.

Hogenhout, S. A., Ammar, E.-D., Whitfield, A. E., and Redinbaugh, M. G. 2008. Insect vector interactions with persistently transmitted viruses. Annu. Rev. Phytopathol. 46:327-359.

Jiao, X., Xie, W., Guo, L., Liu, B., Wang, S., Wu, Q., and Zhang, Y. 2014. Differing effects of cabbage and pepper on $\mathrm{B}$ and $\mathrm{Q}$ putative species of Bemisia tabaci. J. Pest Sci. 87:629-637.

Kenyon, L., Tsai, W.-S., Shih, S.-L., and Lee, L.-M. 2014. Emergence and diversity of begomoviruses infecting solanaceous crops in East and Southeast Asia. Virus Res. 186:104-113.
Kil, E.-J., Byun, H.-S., Kim, S., Cho, S., Cho, S., Roh, K., Lee, K.-Y., Choi, H.-S . Kim, C.-S., and Lee, S. 2015. Tomato yellow leaf curl virus can overwinter in Stellaria aquatica, a winter-hardy TYLCV-reservoir weed. Plant Dis. 99: 588-592.

Kil, E.-J., Byun, H.-S., Kim, S., Kim, J., Park, J., Cho, S., Yang, D.-C., Lee, K.-Y., Choi, H.-S., Kim, J.-K., and Lee, S. 2014a. Sweet pepper confirmed as a reservoir host for tomato yellow leaf curl virus by both agro-inoculation and whitefly-mediated inoculation. Arch. Virol. 159:2387-2395.

Kil, E.-J., Park, J., Lee, H., Kim, J., Choi, H.-S., Lee, K., Kim, C.-S., and Lee, S. 2014b. Lamium amplexicaule (Lamiaceae): A weed reservoir for tomato yellow leaf curl virus (TYLCV) in Korea. Arch. Virol. 159:1305-1311.

Kollenberg, M., Winter, S., and Götz, M. 2014. Quantification and localization of watermelon chlorotic stunt virus and tomato yellow leaf curl virus (Geminiviridae) in populations of Bemisia tabaci (Hemiptera, Aleyrodidae) with differential virus transmission characteristics. PLoS One 9:e111968.

Lapidot, M., Friedmann, M., Pilowsky, M., Ben-Joseph, R., and Cohen, S. 2001. Effect of host plant resistance to tomato yellow leaf curl virus (TYLCV) on virus acquisition and transmission by its whitefly vector. Phytopathology 91:1209-1213.

Legarrea, S., Barman, A., Marchant, W., Diffie, S., and Srinivasan, R. 2015 Temporal effects of a begomovirus infection and host plant resistance on the preference and development of an insect vector, Bemisia tabaci, and implications for epidemics. PLoS One 10:e0142114.

Li, G., Zhao, L., Wang, X., Gao, Y., Sun, G., and Zhu, X. 2014. New natural hosts of tomato yellow leaf curl virus identified in and near tomato-growing greenhouses in eastern China. J. Gen. Plant Pathol. 80:449-453.

Lorenzo, M. E., Grille, G., Basso, C., and Bonato, O. 2016. Host preferences and biotic potential of Trialeurodes vaporariorum and Bemisia tabaci (Hemiptera: Aleyrodidae) in tomato and pepper. Arthr.-Plant Inter. 10:293-301.

Malmstrom, C. M., Melcher, U., and Bosque-Pérez, N. A. 2011. The expanding field of plant virus ecology: Historical foundations, knowledge gaps, and research directions. Virus Res. 159:84-94.

Michelson, I., Zamir, D., and Czosnek, H. 1994. Accumulation and translocation of tomato yellow leaf curl virus (TYLCV) in a Lycopersicon esculentum breeding line containing the $L$. chilense TYLCV tolerance gene $T y-1$. Phytopathology 84:928-933.

Morilla, G., Janssen, D., García-Andrés, S., Moriones, E., Cuadrado, I. M., and Bejarano, E. R. 2005. Pepper (Capsicum annuum) is a dead-end host for tomato yellow leaf curl virus. Phytopathology 95:1089-1097.

Moriones, E., and Navas-Castillo, J. 2000. Tomato yellow leaf curl virus, an emerging virus complex causing epidemics worldwide. Virus Res. 71:123-134.

Muñiz, M., and Nombela, G. 2001. Bemisia tabaci: A new clip-cage for biological studies. FAIR6-CT98-4303. European Whitefly Studies Network, John Innes Centre, Norwich, U.K.

Papayiannis, L. C., Katis, N. I., Idris, A. M., and Brown, J. K. 2011. Identification of weed hosts of tomato yellow leaf curl virus in Cyprus. Plant Dis. 95:120-125.

Polston, J. E., Cohen, L., Sherwood, T. A., Ben-Joseph, R., and Lapidot, M. 2006. Capsicum species: Symptomless hosts and reservoirs of tomato yellow leaf curl virus. Phytopathology 96:447-452.

Polston, J. E., McGovern, R. J., and Brown, L. G. 1999. Introduction of tomato yellow leaf curl virus in Florida and implications for the spread of this and other geminiviruses of tomato. Plant Dis. 83:984-988.

Prendeville, H. R., Ye, X., Jack Morris, T., and Pilson, D. 2012. Virus infections in wild plant populations are both frequent and often unapparent. Am. J. Bot. 99: 1033-1042.

Raybould, A. F., Maskell, L. C., Edwards, M.-L., Cooper, J. I., and Gray, A. J. 1999. The prevalence and spatial distribution of viruses in natural populations of Brassica oleracea. New Phytol. 141:265-275.

Riley, D. G., and Srinivasan, R. 2019. Integrated management of tomato yellow lea curl virus and its whitefly vector in tomato. J. Econ. Entomol. 112:1526-1540.

Rojas, M. R., Gilbertson, R. L., Russell, D. R., and Maxwell, D. P. 1993. Use of degenerate primers in the polymerase chain reaction to detect whiteflytransmitted geminiviruses. Plant Dis. 77:340-347.

Rubinstein, G., and Czosnek, H. 1997. Long-term association of tomato yellow leaf curl virus with its whitefly vector Bemisia tabaci: Effect on the insect transmission capacity, longevity and fecundity. J. Gen. Virol. 78:2683-2689.

Salati, R., Nahkla, M. K., Rojas, M. R., Guzman, P., Jaquez, J., Maxwell, D. P., and Gilbertson, R. L. 2002. Tomato yellow leaf curl virus in the Dominican Republic: Characterization of an infectious clone, virus monitoring in whiteflies, and identification of reservoir hosts. Phytopathology 92:487-496.

Sánchez-Campos, S., Navas-Castillo, J., Monci, F., Díaz, J. A., and Moriones, E 2000. Mercurialis ambigua and Solanum luteum: Two newly discovered natural hosts of tomato yellow leaf curl geminiviruses. Eur. J. Plant Pathol. 106:391-394.

Scholthof, K.-B. G., Adkins, S., Czosnek, H., Palukaitis, P., Jacquot, E., Hohn, T., Hohn, B., Saunders, K., Candresse, T., Ahlquist, P., Hemenway, C., and Foster, G. D. 2011. Top 10 plant viruses in molecular plant pathology. Mol. Plant Pathol. 12:938-954.

Shah, M. M. R., and Liu, T.-X. 2013. Feeding experience of Bemisia tabaci (Hemiptera: Aleyrodidae) affects their performance on different host plants. PLoS One 8:e77368.

Shirazi, M., Mozafari, J., Rakhshandehroo, F., and Shams-Bakhsh, M. 2014 Genetic diversity, host range, and distribution of tomato yellow leaf curl virus in Iran. Acta Virol. 58:128-136. 
Smith, H. A., Nagle, C. A., MacVean, C. M., Vallad, G. E., van Santen, E., and Hutton, S. F. 2018. Comparing host plant resistance, repellent mulches, and at-plant insecticides for management of Bemisia tabaci MEAM1 (Hemiptera: Aleyrodidae) and tomato yellow leaf curl virus. J. Econ. Entomol. 112: 236-243.

Smith, H. A., Seijo, T. E., Vallad, G. E., Peres, N. A., and Druffel, K. L. 2015. Evaluating weeds as hosts of tomato yellow leaf curl virus. Environ. Entomol. 44:1101-1107.

Srinivasan, R., Riley, D., Diffie, S., Sparks, A., and Adkins, S. 2012. Whitefly population dynamics and evaluation of whitefly-transmitted tomato yellow leaf curl virus (TYLCV)-resistant tomato genotypes as whitefly and TYLCV reservoirs. J. Econ. Entomol. 105:1447-1456.

Su, Q., Preisser, E. L., Zhou, X. M., Xie, W., Liu, B. M., Wang, S. L., Wu, Q. J., and Zhang, Y. J. 2015. Manipulation of host quality and defense by a plant virus improves performance of whitefly vectors. J. Econ. Entomol. 108:11-19.

Thompson, J. D., Higgins, D. G., and Gibson, T. J. 1994. CLUSTAL W: Improving the sensitivity of progressive multiple sequence alignment through sequence weighting, position-specific gap penalties and weight matrix choice. Nucleic Acids Res. 22:4673-4680.

Ucko, O., Cohen, S., and Ben-Joseph, R. 1998. Prevention of virus epidemics by a crop-free period in the Arava region of Israel. Phytoparasitica 26:313-321.

Webster, T. M., and MacDonald, G. E. 2001. A survey of weeds in various crops in Georgia. Weed Technol. 15:771-790.

Webster, T. M., and Nichols, R. L. 2012. Changes in the prevalence of weed species in the major agronomic crops of the Southern United States: 1994/ 1995 to 2008/2009. Weed Sci. 60:145-157.

Wintermantel, W. M., Cortez, A. A., Anchieta, A. G., Gulati-Sakhuja, A., and Hladky, L. L. 2008. Co-infection by two criniviruses alters accumulation of each virus in a host-specific manner and influences efficiency of virus transmission. Phytopathology 98:1340-1345.

Wise, A. M., Grey, T. L., Prostko, E. P., Vencill, W. K., and Webster, T. M. 2009. Establishing the geographical distribution and level of acetolactate synthase resistance of Palmer amaranth (Amaranthus palmeri) accessions in Georgia. Weed Technol. 23:214-220. 